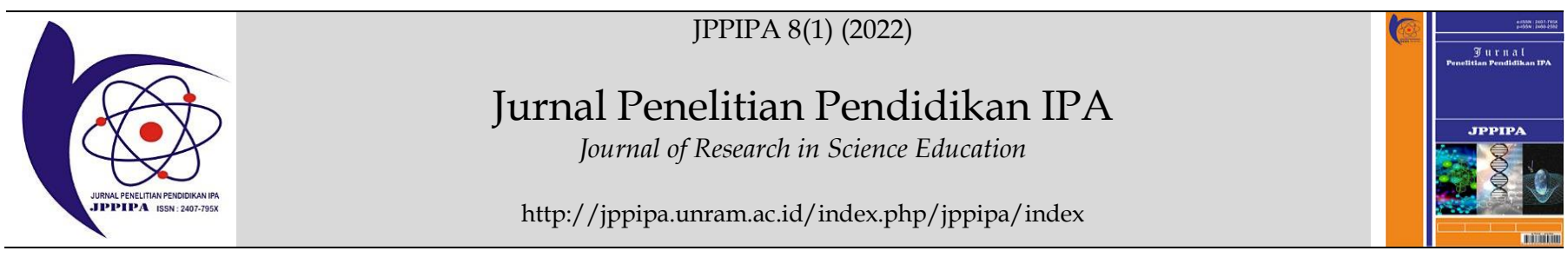

\title{
Development of INoSIT (Integration Nature of Science in Inquiry with Technology) Learning Models to Improve Science Literacy: A Preliminary studies
}

\author{
Amiruddin Takda ${ }^{1,2^{*}}$, Budi Jadmiko ${ }^{3}$, Erman $^{3}$ \\ ${ }^{1}$ Department of Physics Education, Halu Oleo University, Kendari, Indonesia. \\ ${ }^{2}$ Doctoral Student in Department of Science Education, State University of Surabaya, Surabaya, Indonesia. \\ ${ }^{3}$ Professor in Department of Science Education, State University of Surabaya, Surabaya, Indonesia
}

DOI: $\underline{10.29303 / \text { ippipa.v8i1.957 }}$

\section{Article Info}

Received: September 12, 2021

Revised: November 25, 2021

Accepted: December 20, 2021

Published: January 31, 2022

\begin{abstract}
Has successfully created the INoSIT learning paradigm to increase students' science literacy competency. This design aims to integrate information and communication technology (ICT) with inquiry and nature of science (NoS) models to teach scientific literacy to junior high school students using a multi-representation method. The BSCS 5E model (Involvement of Biological Science Curriculum Study, Exploration, Explanation, Elaboration, and Evaluation) and the IBL model (Investigation-based learning) have many phases whose implementation requires many processes. So, the INoSIT model is designed to simplify multiple phases or sub-phases. As a result, IBL (inquiry-based learning) is ineffective and inefficient in terms of learning time. It is also challenging to teach scientific literacy of abstract concepts using this method. The study employs a descriptive analysis method in conjunction with a literature review pattern. The INoSIT model with the syntax Eliciting, Hypothesis, Testing Hypothesis, Elucidation, and Reflection was created from the results of the investigation of the weaknesses of the BSCS 5E (Biological Science Curriculum Study Engagement, Exploration, Explanation, Elaboration, and Evaluation) and the IBL (Inquiry-based learning) models. To construct students' knowledge of literacy and the study is anticipated to contribute to creativity, originality, and the development of a proclivity for inquiry and research.
\end{abstract}

Keywords: INoSIT (Integration Nature of Science in Inquiry with Technology); Literacy science; Inquiry-based learning; BSCS 5E

Citation: Takda, A., Jadmiko, B., \& Erman, E. (2022). Development of INoSIT (Integration Nature of Science in Inquiry with Technology) Learning Models to Improve Science Literacy: A Preliminary studies. Jurnal Penelitian Pendidikan IPA, 8(1), 18-31. https:// doi.org/10.29303/jppipa.v8i1.957

\section{Introduction}

Many scientists have improved students' understanding of Nature of Science and scientific inquiry through science education reform (NRC, 1996; Lederman, 2013). Science education aims to assist students in developing a sufficient understanding of the Nature of Science and scientific inquiry (SI) as components of scientific literacy (NRC, 1996; Lederman, 2013). According to Wenning (2006) \& Saputro, et al. (2021) someone who is literate like science will understand the content and history of at least one field of science, as well as knowledge of scientific nomenclature, intellectual process skills, rules of scientific evidence, postulates science, scientific dispositions, and significant misconceptions about the nature of science. Scientific literacy focuses on increasing students' knowledge by applying scientific concepts in meaningful ways, thinking critically, and balancing. Appropriate judgments on topics that are relevant to their life thus, one of the critical skills of the twenty-first century is the necessity to consider 
scientific literacy for individuals who can access, read, and comprehend the global world through science and technology, then make judgments and utilize that evaluation to inform and make decisions daily (Okada, 2013)

According to the PISA 2015 Framework, it is possible to measure students' scientific literacy skills in three ways: (1) knowledge, (2) competencies, and (3) attitudes. It comprises an evaluation of content knowledge, (ii) an assessment of procedural knowledge, and (iii) an assessment of epistemic knowledge in the knowledge component. Explaining scientific phenomena, assessing and designing scientific studies, and analyzing scientific data and evidence are examples of competencies. The next component of attitude is the attitude toward science, which includes curiosity in research and technology, environmental awareness, and the importance of the scientific method to inquiring. According to the PISA survey findings, Indonesian students continue to have an insufficient level of scientific literacy, which is still at level 1 with a range of 335409 points. Their scientific understanding is still restricted, and they can only apply what they know in a few instances. Students have a level 1 of scientific literacy, which means they can only offer simple scientific explanations and follow the evidence supplied directly (OECD, 2009). It indicates that Indonesian students' average scientific literacy capacity at the age of 15 has only achieved the ability to recognize fundamental facts. They have not communicated or linked their abilities to diverse scientific topics, let alone apply complex and abstract concepts.

The results of various theoretical and empirical studies of multiple models approach and learning strategies in terms of literacy training are needed to improve the achievement of the scientific-educational objectives in schools, keeping with the philosophical basis for the 2013 curriculum developed-School science. In principle, it always leads to two models of learning: the BSCS 5E learning cycle model and the learning model based on inquiry. The 5E model Roger Bybee initially created at the beginning of 1980 has led to an overall philosophy of learning essential founded on the theory of constructivism. Experts from numerous fields, variations of topics, and grades describe the BSCS 5E learning cycle model (Liu, et al., 2009). The $5 \mathrm{E}$ model of a course can allow students to concurrently acquire science abilities that improve their classroom experience and comprehension (Bybee, 2002). Other research findings, such as favorable responses to writing laboratory activity reports and practical applications, demonstrate that the $5 \mathrm{E}$ learning cycle learning model successfully increases students' scientific literacy. Students' capacity to apply science knowledge to real-world problems may increase due to changes in their writing and vocal communication abilities during the Implementation of the 5E learning cycle (Hagerman, 2012 \& Patel, 2019).

Although several benefits have been mentioned in the BSCS 5E learning cycle model, however, both the Learning Cycle Model and BSCS-5E lack practicality from numerous study results, which means that a teacher has little command of the topic needs much time and low learning efficiency (Wilson et al. 2010). In addition, Norwood (2019) said the BSCS 5E model is weak by teacher impression that advanced facilities are needed while hard to get, a lack of administration support, and the environment at school that does not change it. Many scientific concepts are too complex. Abstract and challenging to understand, science is irrelevant to students' lives, and simply not enough time to teach science. Butterick, (2012) noted that specific potential barriers had been identified to the Implementation of the BSCS 5E model, namely: lack of familiarity with the student learning investigative evidence, namely perceived lack of respect for knowhow and skills necessary to the study; the use of scientific and pedagogical terms restricted to teachers; difficulty in equipment and materials; and For example, activities in the engagement phase are difficult to do; lack of suitable terminology; and not familiar with the maps of mind. These authors also note that instructors feel that class dimensions, time planning, the atmosphere in the classroom, science, and financing have significant gaps with predicted success (Butterick, 2012).

Another approach for learning that can assist in improved scientific literacy in classrooms is the IBL model. According to Harlen (2004), research-based scientific education enables students to study and understand the nature and behavior of the universe via mental and physical abilities. This learning method is congruent with the current understanding of the nature and exercise of scientific work. The availability of a supportive learning environment that actively includes students in research, problem-solving, and decisionmaking activities in a relevant context would help to acquire scientific knowledge. Therefore, the fundamental learning activities to attain scientific literacy are scientific research activities. Questions that may be resolving by scientific research activities, scientific knowledge, and features of scientific inquiry are at the center of the inquiry activities - research on particular issues in scientific science. The IBL approach is the most significant way of achieving scientific literacy because it can engage students in discussing and discussing scientific ideas.

While there are numerous advantages to inquirybased learning for students, the implementation 
process in the classroom presents some challenges. Researchers have demonstrated the systemic difficulties of students undertaking scientific research. Data collection, analysis, data interpretation, and communication are demanding activities made more difficult by the requirements of topic expertise (Krajcik, et al. 1998). Investigative education is often inappropriate since the time spent is limited, research is insufficient to include abstractive concepts, the lack of expertise, experience, and background of science teachers has resulted in ineffective enforcement of inquiry learning (Türkmen, 2009). Based on the results of the analysis of the weaknesses of the BSCS 5E learning cycle learning model and the shortcomings of the IBL learning model to teach scientific literacy to students, it can be concluded that some of the weaknesses of the two models are: (1) less effective because it requires much time in conducting investigative activities ; (2) difficulties in conducting scientific investigations systematically (data collection, analysis, data interpretation, and communication); (3) difficulty in preparing equipment and materials; and (4) insufficient attention to student-centered activities related to various representations; and (5) difficulty understanding and investigating abstract concepts.

To overcome the shortcomings of the BSCS $5 \mathrm{E}$ learning cycle learning model and the IBL learning model. One alternative solution is to develop an integrated learning model of inquiry and the nature of science assisted by information and communication technology (ICT), also known as the integrated nature of science (NoS) in inquiry with Technology (INoSIT). This INoSIT model may teach both tangible and abstract ideas of scientific literacy. Concrete ideas necessitate the use of laboratory equipment or KIT, whereas abstract concepts require interactive simulations. Therefore, the students can collectively learn what helps resolve difficult situations by using the INoSIT learning paradigm. The INoSIT model demonstrates how scientific literacy research, like graphical interpretation, interactive simulations, and other types of representation, stems from practical actions during simultaneous cognitive and data processing processes (Roth \& Lee, 2004; Jornet, 2015). The INoSIT paradigm can also provide an alternate method to overcome the challenges of implementing inquiry-based learning (Ergul et al., 2011). When laboratory work cannot be completed at school, ICT in the form of interactive simulations can be utilized to substitute it (Cimer, 2007). Thus, via animations that aid improved comprehension of abstract science topics, teachers can support students' conceptual knowledge of the unseen (abstract) world (Hwang \& Squembre, 2003; Cimer, 2007). Students' high-order thinking abilities, such as application and analysis, can be improved by using simulations in science classes, allowing them to comprehend a topic better. As a result, in complicated experiments, students can anticipate, observe, and investigate the influence of independent factors on the dependent variable.

The INoSIT model proposed in this study focuses on the primary goal of teaching science to train science literacy for junior high school students, which requires students to participate in inquiry activities by conducting investigative activities with the help of science KIT equipment for concrete concepts and abstract concepts with the help of technology in the form of interactive simulations for abstract ideas. So, the students can engage in activities in a variety of representations or multiple representations. The INoSIT model developed is also in line with the 2013 Curriculum. It has been stated that ICT subjects and Computer Skills and Information Management (KPI) are no longer compulsory subjects in schools but will be integrated into all subjects. The form of ICT integration in learning combines materials, pedagogy, and technology, better known as the Technological Pedagogical and Content Knowledge (TPACK) framework. This study aims as a preliminary study in the study of the development of the INoSIT learning model. This study aims to conduct an assessment related to the development of the INoSIT learning model that has increased the scientific literacy competence of junior high school students.

\section{Science Literacy}

Research For the past four decades, the phrase "scientific literacy" has been used extensively in the literature. The meaning conveyed, however, is not necessarily the same. "Whether one was to become a scientist or not," Deboer (2000) stated, "scientific literacy was to give a comprehensive grasp of science and the rapidly growing scientific endeavor." Scientific literacy is designed for all students, whether or not they plan to pursue a career as a scientist. According to the National Science Education Standards (NRC, 1996), scientific literacy defines as the ability to ask, acquire, or decide answers to questions arising from everyday experiences. Holbrook \& Rannikmae (2009) developed a new definition of scientific literacy that will target science education. They suggest the need to appreciate the nature of science and its relevance to science learning achievement. Developing scientific literacy through science education is to develop students' ability to use scientific knowledge and skills creatively based on sufficient evidence, especially those relevant to careers and everyday life in solving problems important and challenging issues in making socialscience decisions responsibly. 
Another concept that aligns with the 2015 PISA Framework's definition of scientific literacy (OECD, 2013) is that scientific literacy shows that scientific ideas are expressed. On the other hand, scientific literacy refers to the capacity to evaluate the quality of information and arguments provided by scientists and in the media using data and evidence (Dragoş \& Mih, 2015). Furthermore, there are numerous measures of scientific literacy, namely (1) Contexts, (2) Knowledge, (3) Competencies, and (4) Attitudes.

\section{Model SBCS $5 E$}

The learning cycle model was first developed by Limniou, et al. (2007) and Liu et al. (2009). His research shows that learning cycles are used to facilitate concept development at the elementary level and are also effective in secondary schools regarding conceptual change and reasoning. This learning cycle model uses a specific sequence of three teaching phases designed for conceptual change. The first phase of this teaching is exploration, which involves students' experience finding the abstract where the concept is explored from the data obtained during the investigation. Finally, students can apply concepts by conducting meaningful studies and using them (Tobin, 1993; Duran \& Duran, 2004; Dagys, 2017).

In its development, the learning cycle became a $5 \mathrm{E}$ learning cycle model. The $5 \mathrm{E}$ learning cycle model was first developed by Roger Bybee in the early 1980s, leading to a general philosophy of teaching and learning that is firmly based on constructivism learning theory. Furthermore, by Bybee (2006), the BSCS 5E model complements the phases contained in the learning cycle model. The BSCS (Biology Science Curriculum Study) model $5 \mathrm{E}$ is implemented in five stages: engagement, exploration, explanation, elaboration, and evaluation. The pedagogy of the BSCS $5 \mathrm{E}$ model is based on the philosophy of John Herbart in the early 20th century, which summarizes into a teaching model that starts with students' prior knowledge and their new ideas related to the prior knowledge they currently have. The relationship between prior knowledge and new ideas ultimately forms the concept. According to Herbart, the best pedagogy of the BSCS 5E model is to involve and direct students to find relationships between their experiences (Daily, 2010). As a learning model with the characteristics of the support of learning theory with the syntax sequence Engagement, Exploration, Explanation, Elaboration, and Evaluation.

In the context of research-based learning or brainstorming in the classroom, the 5E learning cycle (learning cycle 5E) is one of the full constructivist models. Students are at the heart of learning cycle 5E, which includes activities that serve as a foundation for observation, data gathering, and analysis of actions, events, and phenomena (Haribhai \& Dhirenkumar, 2012). Learning cycle $5 E$ is a set of activity stages (phases) arranged to acquire the skills required for learning by taking an active role in the process. The $5 \mathrm{E}$ learning cycle (learning cycle 5E) encourages students to engage in various learning phases to investigate the subject, create definitions for their experiences, obtain more specific information about their learning, and evaluate.

The BSCS 5E model has the following flaws: (1) each learning process requires complete laboratory tools and materials; (2) inefficient, requires much time in investigative activities, and is less effective if the teacher lacks mastery of the material; (3) proficient in memorizing one material, but less able to expand knowledge in real-life situations; (4) laboratory access is difficult; (6) In the explore phase, the teacher does not think much about how to direct students' questions by using inquiry skills; (7) Students have a weakness in learning about abstract concepts (Bybee, 2002; Taner, 2010.

\section{Inquiry Learning Model}

The inquiry-based learning model is another learning paradigm that best promotes growing scientific literacy in schools (Khalaf, 2018). According to Harlen (2004), inquiry-based scientific learning entails students gaining knowledge by utilizing mental and physical abilities to gather information about the universe's nature and behavior. This learning method is in line with current understandings of the nature of the scientific activity and how it is carried out. Learning through inquiry means that students learn by experience and apply their knowledge and learning about how to learn. These two things are significant in the goal of science education, namely the realization of a science-literate society.

Inquiry-based learning has been recommended by the National Research Council (NRC, 1996) to support the development of students' scientific literacy. Students need to identify inquiry abilities to combine scientific processes with scientific knowledge. The basic skills required to work in science and an understanding of scientific inquiry are: (1) scientific investigation involves asking questions and answers and then comparing the answers with what scientists already know about the universe; (2) scientists use different investigations depending on the question they are trying to answer; (3) simple instruments, such as forces, measuring devices and rules that provide more information than scientists obtain using only their senses; (4) scientists develop explanations using observations (evidence) and what they already know about the universe (scientific knowledge); (5) scientists 
make the results of their investigations public; they describe their investigations in a way that allows others to repeat the investigation; (6) scientists conduct reviews and ask questions about the work of other scientists.

The same view on the K-12 Framework for science education (NRC, 2012) emphasizes that "involvement in scientific investigations requires not only knowledge but also skills."This proposal places the form of "inquiry," which is the "practical" form umbrella. Practically further explained by the Next Generation Science Standards (Achieve, 2013) with the following aspects: (1) asking questions and defining problems, (2) developing and using models; (3) planning and conducting investigations, (4) analyzing and interpreting data, (5) using mathematics and computational thinking, (6) constructing explanations and designing solutions, (7) engaging in arguments from evidence, (8) obtaining, evaluating, and communication information. These eight aspects will not be needed in every inquiry activity, but they are a value rule that supports practical inquiry in the classroom. In addition, it can be said that these aspects are essential for students to understand inquiry and develop critical thinking skills.

Table 1. Inquiry Learning Model Phase Revised (Pedaste et al. 2015)

\begin{tabular}{|c|c|c|}
\hline General Phases & Definition & Sub-phases \\
\hline Orientation & $\begin{array}{l}\text { The process of stimulating curiosity on topics aimed at learning challenges } \\
\text { through presenting problems }\end{array}$ & - \\
\hline \multirow[t]{2}{*}{ Conceptualization } & \multirow[t]{2}{*}{ The process of asking questions based on theory or hypothesis } & Questioning \\
\hline & & Hypothesis Generation \\
\hline Investigation & $\begin{array}{l}\text { Explore the process of planning/experiments, collecting and analyzing } \\
\text { data based on the design of experiments }\end{array}$ & Exploration \\
\hline \multirow[t]{2}{*}{ Investigation } & \multirow{2}{*}{$\begin{array}{l}\text { The process of exploring planning or experimentation, collecting and } \\
\text { analyzing data based on an experimental or exploratory design }\end{array}$} & Experimentation \\
\hline & & Data Interpretation \\
\hline Conclusion & $\begin{array}{l}\text { The process of concluding the data comparing information is based on } \\
\text { data with a hypothesis or research questions. }\end{array}$ & - \\
\hline \multirow[t]{2}{*}{ Discussion } & \multirow{2}{*}{$\begin{array}{l}\text { The process of presenting the results of the acquisition of specific phases } \\
\text { or the whole inquiry cycle by communicating with other groups or } \\
\text { teachers and controlling the overall learning process or phases by } \\
\text { involving reflective activities }\end{array}$} & Communication \\
\hline & & Refleksi Reflection \\
\hline
\end{tabular}

The inquiry learning model has several weaknesses, including (Sari, 2021; Susilo, 2020): (1) time spent conducting investigations on abstract concepts, especially if expertise and teacher experience are lacking; (2) lack of facilities for students to investigate independently; (3) difficulty conducting investigations on abstract concepts, especially if expertise and teacher experience are lacking; and (4) difficulty conducting investigations on abstract concepts, especially if expertise and teacher experience are lacking; (2) imperfect encourage students to ask questions that will help students arrive at solutions; (3) inquiry problems related to the use of time which is the weakness of the experiment, cannot reach the level of cognitive development required for abstract thinking; (4) Students have difficulty conducting scientific investigations systematically which is made more difficult by the need for content knowledge; (5) The five most significant challenges for the successful Implementation of inquiry-based learning are: (a) motivation; (b) accessibility of investigative techniques; (c) background knowledge; (d) management of activity expansion; and (e) the practical constraints of the learning context.

\section{Method}

This article describes the initial design of the INoSIT learning model development obtained by studying the weaknesses of the BSCS 5E learning model and the Inquiry learning model. In this study, the data collection technique was in literature studies, especially in the last two decades. This article examines the weaknesses of the Inquiry learning model and the BSCS 5E learning model, which will be used to develop the INoSIT learning model. This study examines several research studies in the form of journals or books related to the BSCS 5E model and the Inquiry model, especially in the perspective of scientific literacy. The literature studied was obtained through the pages of journals and books indexed by Google Scholar, Scopus, Proquest, IEEE. The literature review study was carried out in the years 2000-2021.

\section{Result and Discussion}

The demand for education in the 21st century is that students must have thought and learning skills. These skills include problem-solving, critical thinking, collaboration, communication skills, and scientific literacy skills, often called scientific literacy. In 
addition, the Unesco Science Report (Fensham, 2008) provides eleven issues related to science and technology education, and three of them are issues related to the nature of science and inquiry (the nature of science and inquiry), scientific literacy issues (science literacy), and the use of science and technology. These three issues are the main components of efforts to achieve scientific literacy skills for students. To solve these issues, a scientifically educated person is required, i.e., someone who knows the importance of science and technology in their life can discuss science in the media, assess public policy, appraise the dangers and advantages of scientific development, and make decisions based on evidence. Various theoretical and empirical research on different models, techniques, and learning strategies to teach scientific literacy usually led to two learning models, namely the learning cycle model, to promote scientific literacy in schools according to the 2013 Curriculum, Inquiry-based learning approach, and BSCS 5E.

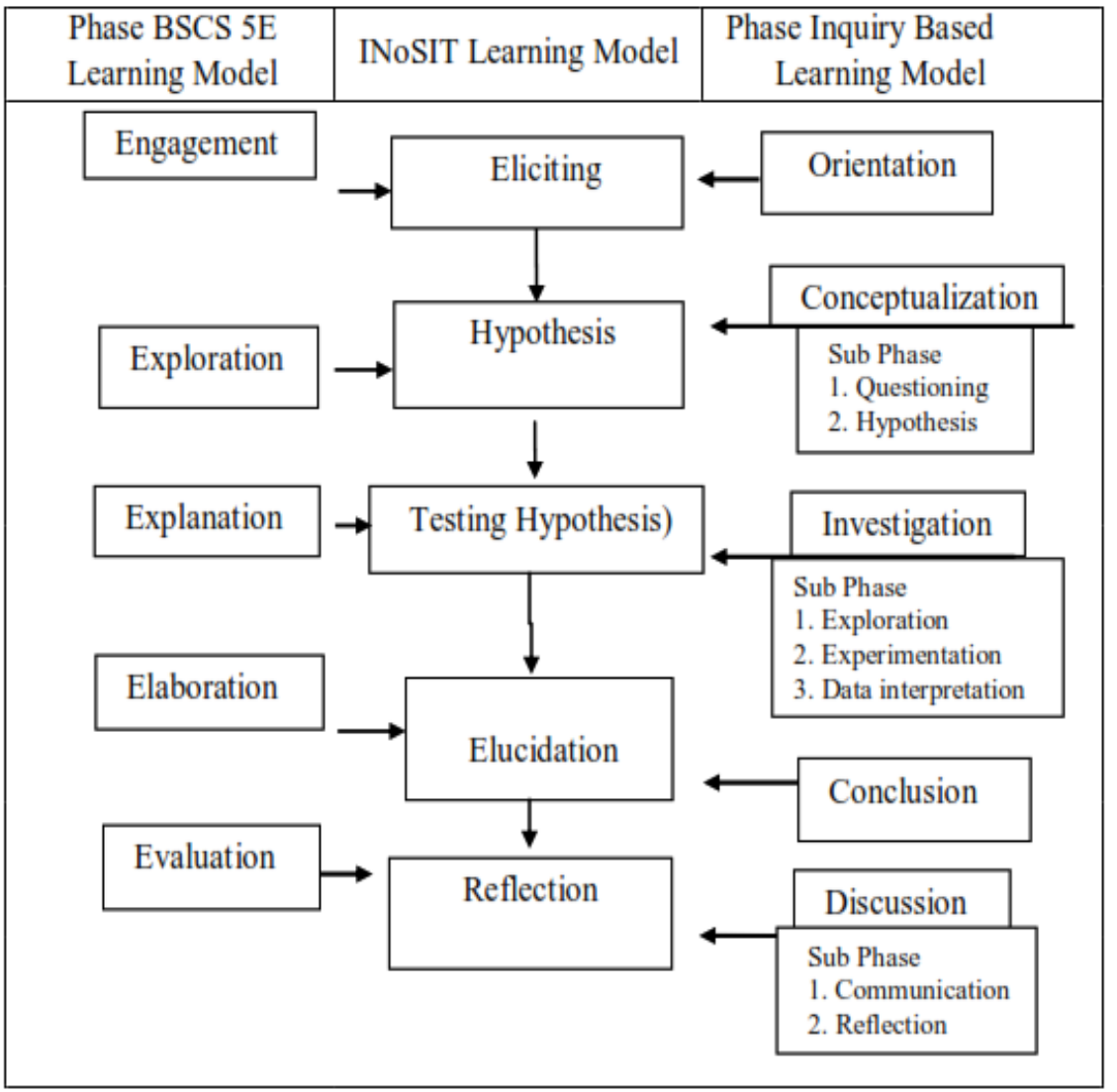

Figure 1: Model Diagram INoSIT were developed based on a model BSCS 5E and Inquiry-Based Learning (IBL)

Based on the results of the analysis of the weaknesses of the BSCS 5E learning cycle learning model and the shortcomings of the IBL model to train students' scientific literacy, it can be concluded that the failings of the two models are: (1) less effective because it requires much time in conducting investigative activities; (2) difficulty conducting scientific investigations systematically (data collection, analysis, data interpretation, and communication); (3) difficulty in preparing equipment and materials; and (4) insufficient attention to student-centered activities related to various representations; and (5) difficulty understanding and investigating abstract concepts.

The shortcomings of the BSCS 5E learning cycle and the inquiry-based learning approach educate pupils' scientific literacy. One alternative solution is developing an INoSIT learning model that can teach scientific literacy on concrete concepts and abstract ideas. The purpose of this proposed model is to integrate Information and Communication Technology (ICT) with an inquiry model and the nature of science with a multi-representation approach in teaching science literacy to junior high school students' inquiry requires students to ask and filter questions, design and conduct investigations, collect and analyze data, make interpretations and conclusions, and report the results obtained. The inquiry will also promote the development, transformation, and representation of ideas; and focuses on deepening rather than expanding (McNeal, et al., 2008). Adding multiple graphics that include symbols, objects, pictures, and mathematical equations such as physics models obtained from ICT 
assistance, indicates that students can enrich scientific understanding. As a result, the INoSIT learning paradigm can assist students in learning cooperatively, which is beneficial for tackling complex issues. Students participate in scientific research such as graphic interpretation, interactive simulations, and other representations as part of the INoSIT model, which emerges from hands-on practical actions during joint cognitive and information processing ability exercises (Roth, 2004; Jornet, 2015). The following is presented in Figure 1, comparing the BSCS 5E learning model, INoSIT, and the inquiry learning model.

The INoSIT model proposed in this study focuses on the primary goal of scientific training literacy for junior high school and equivalent students, requiring students' participation in inquiry. Nature of science (NOS) activities to carry out ICT-assisted investigative activities in interactive simulation that focuses not only on teaching simple concrete science concepts but also on teaching scientific literacy for junior high school and equivalent students. The INoSIT learning model was created in conjunction with the adoption of the 2013 Curriculum, which seeks to increase students' scientific and technological literacy abilities by reinforcing or revitalizing various parts of the previous curriculum. It is also in line with scientific literacy, which teaches students how to apply the scientific method to solve issues in everyday life. In addition, there are demands from teachers in the 21st century learning to create innovative and creative learning integrated with ICT to improve the quality of the learning process in schools.

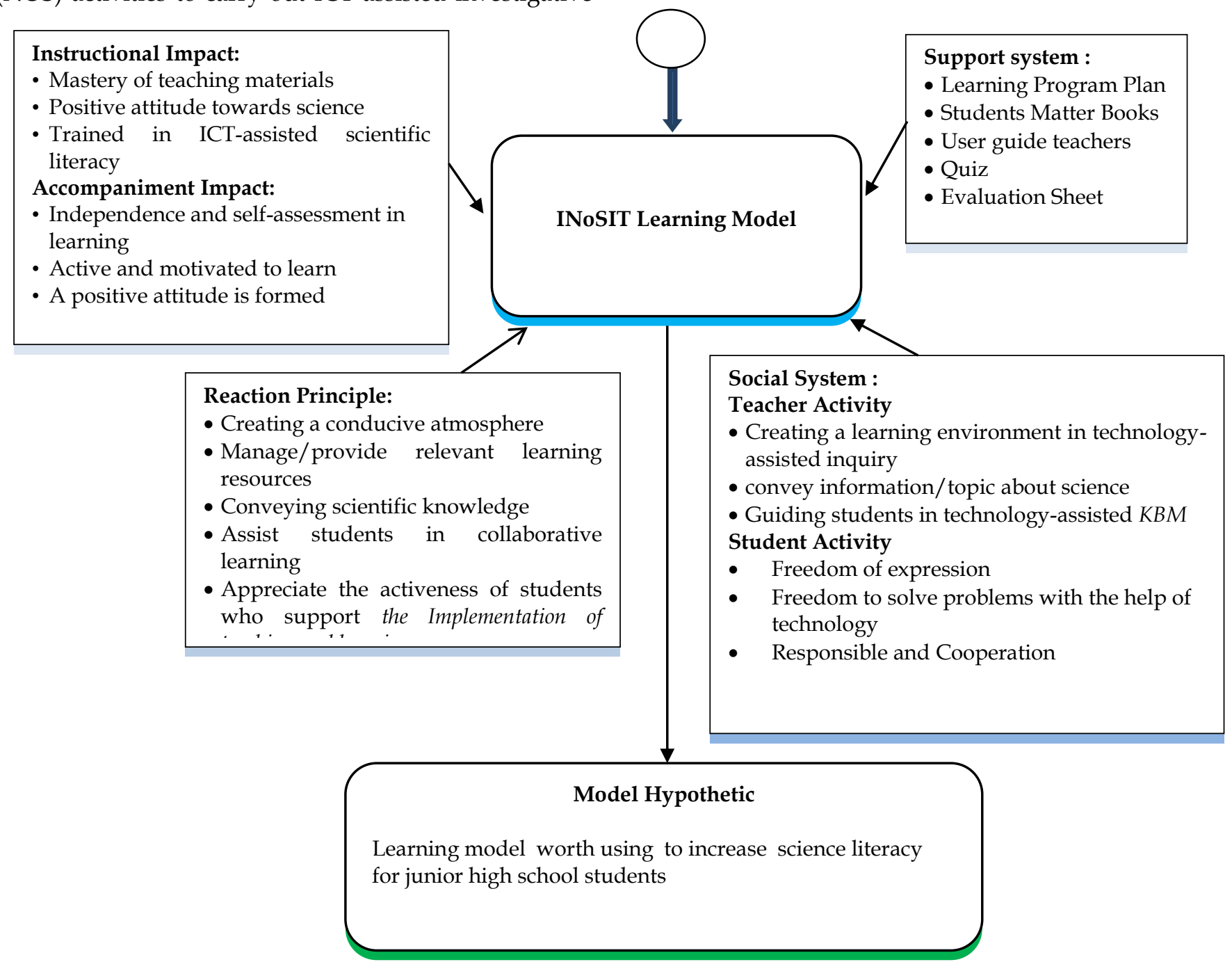

Figure 2: Instructional of INoSIT Model

The learning model developed to train scientific literacy for junior high school students is then named the Integrated Nature of Science and Inquiry with Technology learning model, which is abbreviated as
INoSIT. This learning model consists of five phases (syntax). Each stage of this learning model is interrelated and equally important in achieving learning objectives, increasing scientific literacy 
competence, and mastering concepts. Five phases of the developed INoSIT learning model are interrelating with each other, namely: (1) Elicitating; (2) hypothesis formulation; (3) hypothesis testing; (4) elucidation; and (5) reflection (Figure 2). The INoSIT learning model as a hypothetical model developed is thought to improve scientific literacy competence, which is carried out in a structured manner based on five phases in the model syntax. The five phases are all interconnected and equally vital in accomplishing learning goals. Table 2 shows the mapping design for the five phases of the INoSIT model syntax, namely the objectives, theoretical and empirical support, model syntax, teaching activities, and the learning environment for each step.

Table 2. Syntax of INoSIT Model

\begin{tabular}{|c|c|c|}
\hline Phase & Goals & The Support of Theoretic and Empiric \\
\hline Eliciting & $\begin{array}{l}\text { - Introduction to the topic } \\
\text { and purpose of the } \\
\text { material to be studied } \\
\text { - Conduct simple } \\
\text { experiments with real and } \\
\text { virtual tools on scientific } \\
\text { phenomena and then ask } \\
\text { questions } \\
\text { - generate motivation, } \\
\text { involve students in } \\
\text { question-oriented } \\
\text { scientific investigation } \\
\text { activities }\end{array}$ & $\begin{array}{l}\text { - Students construct new knowledge based on what they already know } \\
\text { (Bransforf \& Schwartz, 1999) } \\
\text { - Keller (1987), to arouse curiosity and interest in learning, students must } \\
\text { pay attention (ARCS theory) and stimulate their curiosity by proposing } \\
\text { problems to be solved through inquiry activities. } \\
\text { - Stimulate or stimulate curiosity about the problem at hand. Learning } \\
\text { topics are introduced to the learning environment provided by the teacher } \\
\text { or defined by the learner (Scanlon et al. 2011) } \\
\text { - In constructivist learning theory, students construct and reconstruct their } \\
\text { knowledge through the process of linking new experiences and prior } \\
\text { knowledge (Llewellyn, 2007) } \\
\text { - Constructivist learning theory, interactive simulation learning occurs } \\
\text { effectively when students engage together on their prior knowledge and } \\
\text { new material experiences in the classroom to develop or conclude their } \\
\text { principles or explanations (Fan \& Geelan, 2012; Collin,1996) } \\
\text { - Focusing students' attention on the learning objectives achieved (Slavin, } \\
\text { 2011), increasing student interest with the relevance of learning objectives } \\
\text { to be obtained by students (Arends, 2012; Moreno, 2010, Slavin 2011); this } \\
\text { is also by the ARCS motivation model (Keller, 2010) }\end{array}$ \\
\hline $\begin{array}{l}\text { Hypothesis } \\
\text { Formulation }\end{array}$ & $\begin{array}{l}\text { Designing inquiry } \\
\text { activities to test } \\
\text { hypotheses } \\
\text { - Asking questions, } \\
\text { determining what to } \\
\text { know, defining and } \\
\text { identifying problems, } \\
\text { - Making predictions, } \\
\text { formulating hypotheses, } \\
\text { solutions, and testing } \\
\text { hypotheses }\end{array}$ & $\begin{array}{l}\text { - Clear learning objectives tend to facilitate better learning } \\
\text { - Clarification of ill-structured concepts (not well defined) has a better effect } \\
\text { on learning depth (Anderson, 2010) } \\
\text { - Establish causal relationships between conceptual and multi- } \\
\text { representational information } \\
\text { - Learning objectives will be fundamental towards facilitating more towards } \\
\text { deeper facilities for } \\
\text { - Specific learning objectives help students to put on investigative questions, } \\
\text { clarification of ill-structured concepts are more influential on the depth of } \\
\text { learning (Anderson, 2010) } \\
\text { - Slavin (2011), regarding cognitive apprenticeship, students gradually } \\
\text { acquire skills through interaction with experts, both adults, and peers. } \\
\text { - Arends (2012), to obtain good knowledge, the teacher should give specific } \\
\text { feedback as soon as possible. } \\
\text { - Santrock (2011), Scaffolding provides support when needed, but guidance } \\
\text { gradually phased out. } \\
\text { - Students explore/observe, design different experiments by changing } \\
\text { variable values, make predictions, and interpret results (De Jong, } 2010 \text { \& } \\
\text { Paas et al. 2003). } \\
\text { - Teachers need to help students create and modify their hypotheses }\end{array}$ \\
\hline $\begin{array}{l}\text { Testing } \\
\text { Hypothesis }\end{array}$ & $\begin{array}{l}\text { - Test the predictions of the } \\
\text { concepts taught using } \\
\text { interactive simulations } \\
\text { - Perform analysis and } \\
\text { representation of evidence, } \\
\text { assess data, determine the } \\
\text { form, evaluate, analyze } \\
\text { data and empirical } \\
\text { evidence to identify } \\
\text { structures and make }\end{array}$ & $\begin{array}{l}\text { - Simulation testing will provide more opportunities to test their predictions } \\
\text { in pairs. Simulations followed by students to manipulate parameters and } \\
\text { changes in observations (De Jong, 2010) } \\
\text { - Establish causal relationships between conceptual and multi- } \\
\text { representational information (Johnson \& Kozma, 1977) } \\
\text { - Provide a virtual learning environment (virtual) where students can test, } \\
\text { develop and evaluate their learning (Gobert \& Buckley 2000) } \\
\text { - Slavin (2006), regarding cognitive apprenticeship, students gradually } \\
\text { acquire skills through interaction with experts, both adults, and peers } \\
\text { - Santrock (2011), Scaffolding provides support when needed, but guidance }\end{array}$ \\
\hline
\end{tabular}




\begin{tabular}{|c|c|c|}
\hline Phase & Goals & The Support of Theoretic and Empiric \\
\hline & $\begin{array}{l}\text { inferences } \\
\text { - Data interpretation, } \\
\text { integration of information } \\
\text { differences that encourage } \\
\text { students' questions, } \\
\text { models, and formulations } \\
\text { of explanations }\end{array}$ & $\begin{array}{l}\text { is slowly removed. } \\
\text { - Students explore/observe, design different experiments by changing } \\
\text { variable values, make predictions, and interpret results (De Jong, 2010; } \\
\text { White \& Frederiksen, 2005). } \\
\text { - Students need support in the interpretation of data collected through } \\
\text { interactive simulations (Fugelsang et al. 2004) }\end{array}$ \\
\hline Elucidation & $\begin{array}{l}\text { - Clarify findings and relate } \\
\text { the results obtained to } \\
\text { scientific concepts } \\
\text { - Conduct discussions, } \\
\text { debate with other groups, } \\
\text { communicate new } \\
\text { understandings, } \\
\text { elaboration, presentation } \\
\text { of new content, and justify } \\
\text { explanations of inquiries }\end{array}$ & $\begin{array}{l}\text { - At the elucidation stage, it allows students to acquire practical skills with } \\
\text { evidence that supports the claims proposed in the Framework for K-12 } \\
\text { Science Education } \\
\text { - Encouraging students to represent their understanding in more than one } \\
\text { way will help develop conceptually (Tytler \& Prain, 2010) } \\
\text { - Scanlon et al. (2011); White et al. (1999) conclude that students will answer } \\
\text { research questions or hypotheses and consider whether research results } \\
\text { support these answers. Findings of the findings of inquiry-based learning, } \\
\text { responding to research questions or ideas. } \\
\text { - Duschl et al. (2007), students will be more interested in learning when } \\
\text { allowed to convey their ideas to other students, respond to other students' } \\
\text { questions, have evidence of their ideas, and evaluate the benefits of } \\
\text { exchanging ideas. } \\
\text { - Scanlon et al. (2011), communication can be seen as an external process in } \\
\text { which students attend and communicate their findings and conclusions to } \\
\text { others and receive feedback, comments from others. } \\
\text { - Schunk (2012), through discussion applying ways to defend students' } \\
\text { arguments so that their understanding will increase. } \\
\text { - Bruce \& Casey (2012), sometimes listening to others can articulate one's } \\
\text { understanding. }\end{array}$ \\
\hline Reflection & $\begin{array}{l}\text { - evaluate the entire } \\
\text { sequence of inquiry and } \\
\text { further develop } \\
\text { metacognitive inquiry } \\
\text { thinking and deepen } \\
\text { understanding of scientific } \\
\text { concepts } \\
\text { - Reflecting, reasoning } \\
\text { about phenomena } \\
\text { - Predict results from new } \\
\text { experiments }\end{array}$ & $\begin{array}{l}\text { - Strengthening students' ideas and building ideas, reconstructing, and } \\
\text { deepening conceptual understanding, because learning science has a lot to } \\
\text { do with knowledge and skills from one topic that is relevant to another } \\
\text { subject (Mills et al. 2014) } \\
\text { - Reflection is defined as the process of reflecting on anything in the } \\
\text { learner's mind, suggesting how the learning process can be improved } \\
\text { White \& Frederiksen, 1998). } \\
\text { - Metacognitive thinking is founding to be effective in improving student } \\
\text { performance (Boulware-Gooden et al. 2007) } \\
\text { - Metacognitive thinking can monitor students' conceptual understanding } \\
\text { and thought processes (Yuruk et al. 2009) } \\
\text { - Practically, Scaffolding is a must in making tasks more productive for } \\
\text { students (Quintana et al. 2004). } \\
\text { - The help of computer technology that focuses on teaching metacognitive } \\
\text { skills shows a positive influence on learning behavior (Aleven et al. 2006). } \\
\text { - The evaluation is metacognitive activities to develop awareness in their } \\
\text { planning and monitoring of student learning (Georghiades, 2006). } \\
\text { - Learning assessment and self-awareness are components of metacognitive } \\
\text { learning, and learning with metacognitive skills is fundamental to } \\
\text { achieving understanding and developing problem-solving abilities } \\
\text { (Cooper \& Sandi-Urena, 2009). } \\
\text { - Students cannot construct knowledge if there is little opportunity for } \\
\text { metacognitive activity (Bairdd et al. 1991 \& Nismoto, 2018). } \\
\text { - One feature of interactive simulations is that interactive simulations allow } \\
\text { students to reflect on learning as they construct new concepts. }\end{array}$ \\
\hline
\end{tabular}

Based on the characteristics of the learning model in Table 2, namely syntax (phase), objectives, theoretical and empirical support, teacher activities, and the learning environment of the Integrated Nature of Science (NoS) and Inquiry with Technology (INoSIT) learning model to train Science Literacy in junior high school students, then formulated the behavior of teachers and students during the learning process (Table 3). 
Table 3. The behavior of teacher and student in the INoSIT Model

\begin{tabular}{|c|c|}
\hline Syntax & Teacher and Student Behavior \\
\hline $\begin{array}{l}\text { Phase 1: } \\
\text { Eliciting }\end{array}$ & $\begin{array}{l}\text { - Motivate students by displaying interactive simulations through virtual laboratory technology about } \\
\text { dynamic electrical phenomena, then the teacher directs them to observe the visualization, and then leads } \\
\text { them to ask some scientific questions } \\
\text { - The teacher conveys the content of the material and the objectives to be achieved in participating in the } \\
\text { learning } \\
\text { - Students are allowed to make observations on the visualization of dynamic electrical phenomena through } \\
\text { interactive simulations } \\
\text { - students practice conducting simple investigations using interactive simulations oriented to the questions } \\
\text { asked and then writing down their initial ideas }\end{array}$ \\
\hline $\begin{array}{l}\text { Phase 2: } \\
\text { Hypothesis } \\
\text { formulation }\end{array}$ & $\begin{array}{l}\text { - The teacher describes the class situation and then encourages discussion, then guides the class in sequence } \\
\text { with the help of interactive simulation ICT media. } \\
\text { - Guiding students using interactive simulations to formulate problems, create experimental designs and } \\
\text { then develop hypotheses to make predictions, find solutions, and how to test hypotheses } \\
\text { - With the teacher's guidance, students are in small groups or pairs, giving their predictions and explaining a } \\
\text { worksheet that the teacher has prepared. }\end{array}$ \\
\hline $\begin{array}{l}\text { Phase } 3 \text { : } \\
\text { Testing } \\
\text { hypothesis }\end{array}$ & $\begin{array}{l}\text { - The teacher guides students to work collaboratively to carry out experiments with the help of ICT in the } \\
\text { form of interactive simulations. } \\
\text { - With computer-based interactive simulations, teachers guide students to solve prediction problems by } \\
\text { collecting data, analyzing, and testing hypotheses. } \\
\text { - The teacher teaches students to investigate, organize, implement plans, collect, analyze and interpret data } \\
\text { and make inferences based on hypothesis testing through ICT }\end{array}$ \\
\hline $\begin{array}{l}\text { Phase 4: } \\
\text { Elucidation }\end{array}$ & $\begin{array}{l}\text { - With the help of ICT, Teacher students to report claims based on evidence and relate to real life } \\
\text { - The teacher guides students to conduct discussions, debates, share ideas and meetings with other groups, } \\
\text { communicate through presentations, give arguments and expressions, communicate to justify explanations } \\
\text { based on findings. } \\
\text { - The teacher guides the discussion between groups on the results of each group's collaboration that has been } \\
\text { presented. }\end{array}$ \\
\hline $\begin{array}{l}\text { Phase 5: } \\
\text { Reflection }\end{array}$ &  \\
\hline
\end{tabular}

The first phase of the INoSIT model, which will be developed to train scientific literacy in junior high school students, arouse (eliciting) student motivation to activate students' prior knowledge and experiences and clarify them in the following lessons, At this stage, the primary learning activities rely on efforts to arouse students' interest and motivation. In contrast, assessing students' initial understanding of the topics to be studied, such as experimental activities or simple inquiry activities, either with the help of fundamental media tools (KIT) or simulation models; Then proceed by asking some questions or providing a provocative problem situation (provocative event), for example, with computer-assisted simulations and animations. In learning activities, students are first faced with instructional tasks and given opportunities for elicitation and clarification. Motivation in learning aims to increase curiosity and interest in knowledge. This technology has been demonstrated to improve writing skills, generate more and better ideas for making decisions, and increase motivation (Center for Applied Special Technology, 1996).

The second phase is an activity to create hypotheses (hypotheses formulation), which is a continuation of the first phase, which aims to engage students in inquiry learning. The main activity is to answer questions posed through experimental activities. Students are instructed to construct experiments to anticipate the influence of independent factors on the dependent variable by forming hypotheses before conducting experiments. Students work in small groups or pairs under the direction of the teacher, making predictions and presenting explanations based on the worksheets that the teacher has supplied. Starting with some research questions, identifying the variables involved (independent 
variables, dependent variables, and control variables), formulating problems, formulating hypotheses and how to test them, and how to collect and analyze data, students can design a student-centered inquiry-based learning experiment using a computer-based interactive simulation learning environment. In the second phase, the instructor uses KIT media or interactive simulations to present the classroom sequence. It also invites pupils to complete the worksheet (LKIS) that the instructor has prepared, implying that the worksheet (LKIS) contains five steps followed in inquiry learning and scaffolding in education. By employing interactive simulations, such as the University of Colorado's PhET simulation, which may be downloaded for free at $\underline{\text { http://phet.colorado.edu }}$ or by using alternative virtual laboratory models.

The third phase of the INoSIT model is testing the hypothesis that has been formulated in the second phase. In this phase, the main activities are conducting experiments, collecting, analyzing data (conducting experiments, collecting and analyzing data) both with KIT media and with the help of interactive simulation technology based on the results of the experimental design in the second phase. The instructor helps students research, organize, and implement ideas, gather, analyze, and evaluate data and draw conclusions. Then, by conducting experiments and testing hypotheses, lead students in answering prediction problems. Students will have several opportunities to verify their predictions in pairs by participating in this exercise, including interactive simulations. Teachers may spend more time evaluating student learning when they employ simulations rather than concentrating on student safety in the lab.

The fourth phase of the INoSIT model is meaning (Elucidation), focusing on clarifying findings and connecting the results obtained to scientific concepts. It also facilitates conversations and disputes with other groups, conveys new understandings, elaborates, provides further information, and defends inquiry explanations. When the instructor offers explanations (elucidations) of essential concepts, the goal is for pupils to report claims based on evidence and link them to real-life events. Students/groups of students are asked to present their investigation efforts and report their findings based on the evidence. This level allows students to learn and practice how to support their ideas with evidence.

The fifth phase of the INoSIT model developed to train science literacy in junior high schools is evaluation. It is the final step, and its primary goal is to assess the syntactic implementation process and the students' scientific literacy. The instructor engages students in various process assessment tasks to help them become more aware of planning and monitoring their learning.

\section{Conclusion}

Based on the investigation results and study of the BSCS 5E learning model and the inquiry learning model, the INoSIT (Integration Nature of Science in Inquiry with Technology) learning model has been successfully developed. The syntax of the INoSIT (Integration Nature of Science in Inquiry with Technology) learning model consists of Eliciting, Hypothesis, formulation Testing hypothesis, Elucidation, and Reflection. The INoSIT model developed focuses on scientific literacy training for junior high school students and the equivalent and requires student involvement in inquiry and nature of science (NOS) activities.

\section{Acknowledgments}

The author would like to thank the Ministry of Higher Education Technology Research for the Doctoral Dissertation Grant. In addition, the authors gratefully thank Halu Oleo University for their support so that the study can be completed.

\section{References}

Aleven, V., McLaren, B., Roll, I., \& Koedinger, K. (2006). Toward meta-cognitive tutoring: A model of help-seeking with a Cognitive Tutor. International Journal of Artificial Intelligence in Education, 16(2), 101-128. Retrieved from: https://psycnet.apa.org/record/2006-10773-002

Anderson (2010). A Taxonomy for Learning, Teaching, and Assessing; Revision of Bloom's Taxonomy of Educational Objectives. New York: Longman. https:/ libgen.is/book/index.php?md5=C63B3F 3F2399C6971A5F504DAECF23F9

Arends, R.I. (2012). Learning to Teach. $9^{\text {th }}$ Edition. New York: McGraw-Hill Companies, Inc. https://hasanahummi.files.wordpress.com/2017 L04/connect-learn-s...pdf

Baird, J. R., Fensham, P. J., Gunstone, R. F., \& White, R. T. (1991). The importance of reflection in improving science teaching and learning. Journal of research in Science Teaching, 28(2), 163-182. https://doi.org/10.1002/tea.3660280207

Boulware-Gooden, R., Carreker, S., Thornhill, A., \& Joshi, R. M. (2007). Instruction of metacognitive strategies enhances reading comprehension and vocabulary achievement of third-grade 
students. The reading teacher,61(1), 70-77. https://doi.org/10.1598/rt.61.1.7

Bransford, J. D., \& Schwartz, D. L. (1999). Chapter 3: Rethinking transfer: A simple proposal with multiple implications. Review of research in education, 24(1),

61-100.

https://doi.org/10.2307/1167267

Bruce, B. C., \& Casey, L. (2012). The practice of inquiry: A pedagogical 'sweet spot'for digital literacy?. Computers in the Schools, 29(1-2), 191206.

https:// doi.org/10.1080/07380569.2012.657994

Butterick, K. (2012). Pengantar Public Relations: Teori dan Praktik. Jakarta: PT RajaGrafindo Persada

Bybee, R.W. (2002). Scientific inquiry, student learning, and the science curriculum. Learning science and the science of learning, 25-35. Retrieved from: https://my.nsta.org/resource/240

Cimer, A. (2007). Effective teaching in science: A review of literature. Journal of Turkish science education, 4(1), 20-44.

Collins, A. (1996). Design issues for learning environments. International perspectives on the design of technology-supported learning environments, 347-361. https://doi.org/10.4324/9780203053386-26

Dagys, D. (2017). Theoretical Inquiry-Based Learning Insights on Natural Science Education: from the Source to 5E Model. Pedagogika, 126(2), 83-98. https://doi:10.15823/p.2017.21

Daily, Q. (2010). Explicit Nature of Science Instruction and the 5E Learning Cycle: A Gateway to Scientific Literacy. Thesis. Department of Master Science Educatiom, Montane State University.

DeBoer, G. E. (2000). Scientific literacy: Another look at its historical and contemporary meanings and its relationship to science education reform. Journal of Research in Science Teaching, 37(6), 582-601. https://doi.org/10.1002/10982736(200008)37:6<582::aid-tea5>3.0.co;2-1

De Jong, T. (2010). Cognitive load theory, educational research, and instructional design: Some food for thought. Instructional science, 38(2), 105-134. https://doi.org/10.1007/s11251-009-9110-0

Dragoş, V., \& Mih, V. (2015). Scientific literacy in school. Procedia-Social and Behavioral Sciences, 209, 167-172.

https://doi.org/10.1016/j.sbspro.2015.11.273

Duschl, R. A., Schweingruber, H. A., \& Shouse, A. W. (2007). Taking science to school: Learning and teaching science in grades K-8. Eurasia Journal of Mathematics, Science \& Technology Education, 3(2), 163-166. https://doi.org/10.17226/11625

Duran, L. B., \& Duran, E. (2004). The 5E Instructional Model: A Learning Cycle Approach for Inquiry-
Based Science Teaching. Science Education Review, 3(2), 49-58. Retrieved from: https://eric.ed.gov/?id=EJ1058007

Ergül, R., Şımşeklı, Y., Çaliş, S., Özdılek, Z., Göçmençelebı, Ş., \& Şanli, M. (2011). The Effects Of Inquiry-Based Science Teaching On Elementary School Students'science Process Skills And Science Attitudes. Bulgarian Journal of Science $\mathcal{E}$ Education Policy, 5(1).

Fan, X., \& Geelan, D. (2012). Integrating information technology and science education for the future: a theoretical review on the educational use of interactive simulations. In Proceedings of the 2012 Australian Computers in Education Conference (pp. 2-5).

Fensham, P. (2008). Science education policymaking. Eleven Emerging Issues, 1-47.

Fugelsang, J. A., Stein, C. B., Green, A. E., \& Dunbar, K. N. (2004). Theory and data interactions of the scientific mind: Evidence from the molecular and the cognitive laboratory. Canadian Journal of Experimental Psychology/Revue canadienne de psychologie expérimentale, 58(2), 86. https://doi.org/10.1037/h0085799

Georghiades, P. (2006). The role of metacognitive activities in the contextual use of primary pupils' conceptions of science. Research in Science Education, 36(1), 29-49. https://doi.org/10.1007/s11165-004-3954-8

Gobert, J. D., \& Buckley, B. C. (2000). Introduction to model-based teaching and learning in science education. International Journal of Science Education, 22(9), 891-894. https://doi.org/10.1080/095006900416839

Hagerman, C. L. (2012). Effects of the 5E learning cycle on student content comprehension and scientific literacy. A professional paper submitted in partial fulfillment of the requirements for the degree of Master of Science In Science Education.Montana State University Bozeman, Montana July 2012.

Harlen, W. (2004). The Assessment of Scientific Literacy in the OECD/PISA Project. In Helga Behrendt dkk (Eds). Research in Science Education-Past, Present, and Future (p. 49-60). New York, US: Kluwer Academic Publisher.

Haribhai, T. S., \& Dhirenkumar, G. P. (2012). MetaAnalysis of Effectiveness of Computer-Aided Instruction Method. Quest-The Journal of UGCASC Nainital, 6(3), 479-488. https://doi.org/10.5958/j.0974-5041.6.3.038

Holbrook, J., \& Rannikmae, M. (2009). Nature of science education for enhancing scientific literacy. International Journal of Science Education, 29(11), 1374-1362. https://doi.org/10.1080/09500690601007549 
Hwang, F. K., \& Esquembre, F. (2003). Easy java simulations: An interactive science learning tool. Interactive Multimedia Electronic Journal of Computer-Enhanced Learning, 5(2).

National Research Council (NRC). (1996). National Science Education Standards. Washington, DC: National Academy Press

Johnson, O., \& Kozma, A. (1977). Effects of concurrent verbal and musical tasks on a unimanual skill. Cortex, 13(1), 11-16. https://doi.org/10.1016/s0010-9452(77)80049-x

Jornet, A., \& Roth, W. M. (2015). The joint work of connecting multiple (re) presentations in science classrooms. Science Education, 99(2), 378-403. https://doi.org/10.1002/sce.21150

Keller, J. M. (1987). Development and use of the ARCS model of instructional design. Journal of instructional development, 10(3), 2-10. https://doi.org/10.1007/BF02905780

Keller, J. M. (2010). The Arcs model of motivational design. In Motivational design for learning and performance (pp. 43-74). Springer, Boston, MA. https://doi.org/10.1007/978-1-4419-1250-3

Khalaf, B. K. (2018). Traditional and Inquiry-Based Learning Pedagogy: A Systematic Critical Review. International Journal of Instruction, 11(4), 545-564. https://doi.org/10.12973/iji.2018.11434a

Krajcik, J., Blumenfeld, P. C., Marx, R. W., Bass, K. M., Fredricks, J., \& Soloway, E. (1998). Inquiry in project-based science classrooms: Initial attempts by middle school students. Journal of the Learning Sciences, 7(3-4),

313-350. https://doi.org/10.1080/10508406.1998.9672057

Lederman, N. G., Lederman, J. S., \& Antink, A. (2013). Nature of science and scientific inquiry as contexts for the learning of science and achievement of scientific literacy. International Journal of Education in Mathematics, Science and Technology, 1(3).

Llewellyn, D. (2005). Teaching high school science through inquiry: A case study approach. Thousand Oaks: Corwin Press.

Liu, X. (2009). Beyond science literacy: Science and the public. International Journal of Environmental and Science Education, 4(3), 301-311.

Limniou, M., Papadopoulos, N., Giannakoudakis, A., Roberts, D., \& Otto, O. (2007). The integration of a viscosity simulator in a chemistry laboratory. Chemistry Education Research and Practice, 8(2), 220-231. https://doi.org/10.1039/b6rp90032a

Mills, M., Monk, S., Keddie, A., Renshaw, P., Christie, P., Geelan, D., \& Gowlett, C. (2014). Differentiated learning: From policy to classroom. Oxford Review of Education, 40(3), 331348. 2014.911725 https://doi.org/10.1080/03054985.

Moreno, R. (2010). Educational Psychology. New York: John Wiley \& Son Inc.

Nishimoto, M. C. (2018). The Importance of Teacher Induction for Improving Teaching and Learning. The Wiley Handbook of Teaching and Learning, 447471. 9781118955901.ch19

https://doi.org/10.1002/

Norwood, M. (2019). The Impact of the Biological Sciences Curriculum Study (BSCS) 5E Model on Middle-Level Students' Content Knowledge (Doctoral dissertation, University of South Carolina).

Organisation for Economic Cooperation and Development (OECD). (2009). PISA 2009 Assessment Framework, Key Competencies in Reading, Mathematics and Science. Paris: OECD Publications.

Okada, A. (2013). Scientific literacy in the digital age: tools, environments and resources for co-inquiry. European Scientific Journal, 4, 263-274. https://doi.org/10.19044/esj.2013.v9n10p\%25p

Quintana, C., Reiser, B. J., Davis, E. A., Krajcik, J., Fretz, E., Duncan, R. G., \& Soloway, E. (2004). A scaffolding design framework for software to support science inquiry. The journal of the learning sciences, 13(3), 337-386. https://doi.org/10.1207/s15327809jls1303_4

Paas, F., Renkl, A., \& Sweller, J. (2003). Cognitive Load Theory and Instructional Design: Recent Developments. Educational Psychologist, 38(1), 14. https://doi:10.1207/ s15326985ep3801_1

Pedaste, M., Mäeots, M., Siiman, L. A., De Jong, T., Van Riesen, S. A., Kamp, E. T., \& Tsourlidaki, E. (2015). Phases of inquiry-based learning: Definitions and the inquiry cycle. Educational research review, 14, 47-61. https://doi.org/10.1016/j.edurev.2015.02.003

Patel, D. A. (2019). Effects of 5E learning Cycle Model on Achievement in Social Science of Std-8. International Journal of Trend in Scientific Research and Development, 3(3), 1836-1837. https://doi:10.31142/ijtsrd21726

Roth, W. M., \& Lee, S. (2004). Science education as/for participation in the community. Science education, 88(2), 263-291. https://doi.org/10.1002/sce.10113

Santrock, J.W. (2011).Educational Psychology, 5th Edition. New York: McGraw-Hill.

Saputro, A. N. C., Suhelayanti, S., Chabibah, N., Bermuli, J. E., Sinaga, K., Fauzi, A., \& Fayanto, S. (2021). Pembelajaran Sains. Medan: Yayasan Kita Menulis. 
Sari, M. (2021). Pengaruh Model Inquiry terhadap Kemampuan Memahami Teks Deskripsi pada Siswa SMP. At-Tarbawi, 8(1), 33-42. https://doi.org//10.32505/tarbawi.v13i1.2716

Scanlon, E., Anastopoulou, S., Kerawalla, L., \& Mulholland, P. (2011). How technology resources can be used to represent personal inquiry and support students' understanding of it across contexts. Journal of Computer Assisted Learning, 27(6), 516-529. https://doi.org/10.1111/j.1365-2729.2011.0 $\underline{0414 . x}$

Schunk, D. H. (2012). Learning theories an educational perspective sixth Edition. US: Pearson.

Slavin, R, E. (2006). Educational Psychology: Theory and Practices. Bostn: Allyn anc Bacon

Susilo, T. (2020). Pengembangan Pembelajaran Inquiry Bervisi Sets Pada Sistem Pencernaan Untuk Meningkatkan Kecerdasan Emosional Dan Prestasi Belajar. Khazanah Pendidikan, 14(1).

Tanner, K. D. (2010). Order matters: using the 5E model to align teaching with how people learn. $C B E-$ Life Sciences Education, 9(3), 159-164. https:// doi.org/10.1187/cbe.10-06-0082

Tobin, K. G. (1993). The practice of constructivism in science education. Hillsdale: Psychology Press.

Türkmen, H. (2009, April). An effect of technology based inquiry approach on the learning of" Earth, Sun, \& Moon" subject. In Asia-Pacific Forum on Science Learning \& Teaching. 10(1).

Tytler, R., \& Prain, V. (2010). A framework for re-thinking learning in science from recent cognitive science perspectives. International Journal of Science Education, 32(15), 2055-2078. https://doi.org/10.1080/09500690903334849

Wenning, C. J. (2006). Assessing nature-of-science literacy as one component of scientific literacy. Journal of Physics Teacher Education Online, 3(4), 3-14.

White, B. Y., \& Frederiksen, J. R. (1998). Inquiry, modeling, and metacognition: Making science accessible to all students. Cognition and instruction, 16(1), 3-118.

White, B., \& Frederiksen, J. (2005). A theoretical framework and approach for fostering metacognitive development. Educational Psychologist, 40(4), 211-223. https://doi.org/10.1207/s15326985ep4004_3

White, B. Y., Shimoda, T. A., \& Frederiksen, J. R. (1999). Enabling students to construct theories of collaborative inquiry and reflective learning: Computer support for metacognitive development. International Journal of Artificial Intelligence in Education (IJAIED), 10, 151-182.
Wilson, C. D., Taylor, J. A., Kowalski, S. M., \& Carlson, J. (2010). The relative effects and equity of inquiry-based and commonplace science teaching on students' knowledge, reasoning, and argumentation. Journal of Research in Science Teaching: The Official Journal of the National Association for Research in Science Teaching, 47(3), 276-301. https://doi.org/10.1002/tea.20329

Yuruk, N., Beeth, M. E., \& Andersen, C. (2009). Analyzing the effect of metaconceptual teaching practices on students' understanding of force and motion concepts. Research in Science Education, 39(4), 449-475. https://doi.org/10.1007/s11165-008-9089-6 